\title{
Trinta Anos
}

Ao longo do ano que ora está em início, a Revista de Saúde Pública publicará o volume 30 de sua série iniciada em 1967 e mantida ininterrupta durante todo esse período. O nível atingido permite que, na atualidade, o periódico seja procurado pela maioria dos pesquisadores brasileiros em saúde pública/coletiva, para a divulgação de seus trabalhos científicos.

Ter artigo publicado na Revista de Saúde Pública representa algo a ser interpretado com, pelo menos, alguma dose de pioneirismo. Os riscos assumidos frente a eventuais decisões contrárias de relatores e de editores não deveriam ser encaradas como "pedras no caminho" de qualquer programação de estudo. Eis que o papel da Revista vem a ser, de preferência, o de estimular e de abrir novas e mais amplas vias para a pesquisa científica. Dentro dos múltiplos campos do conhecimento que formam a saúde pública/coletiva, compreende-se que se dê preferência àqueles artigos que, além da originalidade, encerrem potencial inovador e de interesse geral, ou seja, passível de projeção para público amplo. Assim, por exemplo, a descoberta de nova doença, de nova relação causal ou de novas soluções com aplicabilidade social. Impõese sempre perguntar se tais descobertas implicariam inovações que redundassem aumento de eficácia da política de saúde pública. Além disso, procura-se divulgar idéias que estimulem a reflexão e resultem em discussões benéficas para o progresso das várias áreas de conhecimento. De todas as maneiras, o que se objetiva é divulgar avanços concretos e de sua aplicabilidade para a qualidade da vida humana.

Nem de longe se pretende ter alcançado a perfeição. Muito há ainda a fazer. No entanto, alguns indicadores mostram o progresso da Revista de Saúde Pública em época mais recente. Pode-se, a seguir, mencionar alguns deles.

O número de revisores por artigo, foi ampliado de dois para três especialistas. Com isso pretende-se maior garantia de acerto na decisão final, graças a mais amplo crivo de qualidade.

Como ponto de honra, procura-se manter a disseminação em bases de dados estrangeiras, obviamente garantindo a indexação nas bases nacionais. Dentre aquelas há de se mencionar a correspondente ao ISI, tida como altamente seletiva. Ora bem, em que pese a Revista de Saúde Pública estar ali ocupando o segundo lugar dentre aquelas da área da saúde, utilizadas por pesquisadores brasileiros, ela é a primeira e única nacional em saúde pública/coletiva, apresentando-se com 2/3 dos artigos* indexados de autoria brasileira.

Sobre o crescimento de artigos submetidos, observou-se mais significativo, a partir de 1994, dobrando em 1995. Até então a Revista recebia entre 100 - 110 artigos/ano; em 1995 foram-lhe submetidos 200 manuscritos. Esta tendência pode estar representando alguma mudança na produção científica na área de Saúde Pública/Coletiva, no País.

Ainda sobre seu crescimento, a Revista vem mantendo a média de 60/65 artigos

* Guimarães, R. \& Vianna, C. M de U. Ciências e tecnologia em saúde. Tendências mundiais. Diagnóstico global e estado da arte no Brasil. In 
publicados anualmente. No espaço entre 1991 a 1995 foram editados 261 artigos, sendo 228 originais e notas e informações (70\%). Publicou ainda artigos sob a rubrica "ponto de vista" e artigos especiais, a partir de 1993. Outras categorias de matéria também foram editadas, entre Editoriais, Notas Bibliográficas e Noticías.

É constante a preocupação do corpo dirigente da Revista em torná-la competitiva no meio nacional e internacional. Várias são as discussões sobre esse aspecto, estendendose também à preocupação sobre o futuro da divulgação de periódicos científicos, tendo em vista as novas tecnologias e a globalização da ciência. Não há ainda planos a curto prazo de transformar a Revista em publicação eletrônica, seja no formato CDRom, seja por redes internacionais. Mas sabe-se que esse é também um caminho, embora com a percepção de que a edição em papel permanecerá, por alguns anos, sobretudo para país como o Brasil. Além do que, tudo isto é ainda muito novo, pois mesmo nos países cientificamente mais adiantados, ainda os formatos eletrônicos estão sendo testados, e a publicação em papel está pelo menos, preventivamente, sendo mantida. A direção da Revista está atenta a essas questões e talvez em 1997 já tenhamos algumas novidades, neste particular.

Fruto das discussões sobre sua internacionalização, está programada, ainda para este ano comemorativo, a versão dos títulos dos artigos das tabelas e dos resumos para o idioma espanhol além do inglês.

Finalmente cabe expressar os agradecimentos a instituições e pessoas que contribuíram, e muito, para que a Revista chegasse a comemorar 30 anos de existência.

Há que se reconhecer o papel exercido pela FAPESP e FINEP, garantindo os recursos para composição e impressão da Revista, e a infra-estrutura de recursos humanos e materiais assegurados pela Faculdade de Saúde Pública/USP, que foram os alicerces para manter em dia a publicação da Revista.

A seguir devemos agradecer aos Editores Associados que, junto com os relatores, vêm participando do processo de julgamento, garantindo o equilíbrio qualitativo necessário à Revista.

Aos autores, não só agradecemos, mas esperamos ter contribuído com algum estímulo para que continuem produzindo suas pesquisas, divulgando-as com o objetivo de alcançar o domínio do conhecimento na área de saúde pública/coletiva no Brasil.

Não existe maior recompensa do que ver o fruto do trabalho, conhecido e apreciado por todos aqueles cuja opinião honra o seu autor. Os que reconhecem na Revista de Saúde Pública o veículo digno para propiciar isso, constituem o público ao qual esse periódico é destinado.

\section{Oswaldo Paulo Forattini Editor Científico}

